\title{
PENGARUH RADIASI SINAR GAMMA TERHADAP KEMAMPUAN DEGRADASI LIGNIN PHANEROCHAETE CHRYSOSPORIUM DAN GANODERMA LUCIDUM
}

\author{
Tri Retno D.L. ${ }^{1}$, Nana Mulyana ${ }^{1}$, Nurhasni ${ }^{2}$, Uswatun Hasanah ${ }^{2}$ \\ ${ }^{1}$ Pusat Aplikasi Isotop dan Radiasi, PAIR-BATAN, JI. Lebak Bulus Raya No.49, Jakarta 12440. \\ ${ }^{2}$ Prodi Kimia, Fakultas Sains dan Teknologi, Universitas Islam Negeri (UIN) Syarif Hidayatullah, \\ JI. Ir. H. Juanda No. 95, Ciputat 15412 \\ e-mail: tretno@batan.go.id
}

\begin{abstract}
ABSTRAK
PENGARUH RADIASI SINAR GAMMA TERHADAP KEMAMPUAN DEGRADASI LIGNIN PHANEROCHAETE CHRYSOSPORIUM DAN GANODERMA LUCIDUM. Penelitian ini bertujuan untuk meningkatkan aktivitas enzim ektraseluler fungi lignoselulotik yakni phanerochaete chrysosporium dan ganoderma lucidum dalam mendegradasi limbah lignoselulosa. Lignoselulosa sulit didegradasi karena terdiri dari lignin, selulosa dan hemiselulosa. Phanerochaete chrysosporium dan ganoderma lucidum dari kelompok white rot fungi dapat mendegradasi lignin karena mampu mensintesa enzim lignin peroksidase (LiP). Iradisi sinar gamma dosis rendah mampu menstimulasi peningkatan aktivitas enzim ekstraselular. Fungi phanerochaete chrysosporium dan ganoderma lucidum dalam medium slent dipapar dengan iradiasi gamma pada dosis 0 (kontrol), 200, 400, 600, 800 dan $1000 \mathrm{~Gy}$. Di dalam medium cair mengandung Potatoes Dextrose Broth (PDB), garam mineral dengan substrat lignin alkali 0 dan $5 \% \mathrm{~b} / \mathrm{v}$, fungi phanerochaete chrysosporium yang dipapar sinar gamma dosis $600 \mathrm{~Gy}$ memiliki aktivitas LiP $(30 \mathrm{U} / \mathrm{mL})$ sebesar 2,5 kali lebih tinggi dibandingkan dengan kontrol $(12 \mathrm{U} / \mathrm{mL})$. Sedangkan ganoderma lucidum yang dipapari radiasi gamma dengan dosis $800 \mathrm{~Gy}$ memiliki aktivitas LiP $(34 \mathrm{U} / \mathrm{mL})$ sebesar 1,7 kali lebih tinggi dibandingkan kontrol $(20 \mathrm{U} / \mathrm{mL})$. Fermentasi padat substrat serbuk kayu jati putih (Gmelina arborea Roxb.) selama 12 hari dengan pH 6,4; dan kadar air $79 \%$ oleh fungi phanerochaete chrysosporium yang diradiasi sinar gamma dosis 600 Gy memiliki efisiensi degradasi lignin sebesar $42 \%$, sedangkan pada fungi ganoderma lucidum yang diradiasi sinar gamma dosis $800 \mathrm{~Gy}$ memiliki efisiensi degradasi lignin sebesar $21 \%$ dengan kondisi optimal $\mathrm{pH} 7,6$ dan kadar air $71,3 \%$.
\end{abstract}

Kata kunci: phanerochaete chrysosporium, ganoderma lucidum, enzim LiP, radiasi sinar gamma, degradasi lignin.

\section{ABSTRACT}

INFLUENCE OF GAMMA RAYS RADIATION ON LIGNIN DEGRADATION POTENCY OF PHANEROCHAETE CHRYSOSPORIUM AND GANODERMA LUCIDUM. This research aims to increase the activity of extracellular enzymes lignolitik fungi phanerochaete chrysosporium and ganoderma lucidum to degrade lignocellulosic waste. Lignocellulosic difficult to degrade because it is composed of lignin, cellulose and hemicellulose. Phanerochaete chrysosporium and ganoderma lucidum group white rot fungi can degrade lignin because it is able to synthesize enzymes lignin peroxidase (LiP). Iradisi low dose gamma rays capable menstimulsi increase extracellular enzyme activity. Fungi phanerochaete chrysosporium and ganoderma lucidum in medium slent exposed to gamma irradiation at doses of 0 (control), 200, 400, 600, 800 and 1000 Gy. In a liquid medium containing Potatoes Dextrose Broth (PDB), mineral salts with the substrate lignin alkali 0 and $5 \% \mathrm{w} / \mathrm{v}$, fungi phanerochaete chrysosporium were exposed to a dose of $600 \mathrm{~Gy}$ of gamma rays have LiP activity $(30 \mathrm{U} / \mathrm{mL})$ by 2.5 times higher compared with controls $(12 \mathrm{U} / \mathrm{mL})$. While ganoderma lucidum that are exposed to gamma radiation at a dose of 800 Gy has LiP activity $(34 \mathrm{U} / \mathrm{mL})$ was 1.7 times higher than the control $(20 \mathrm{U} / \mathrm{mL}$ ). On a solid substrate fermentation of white teak powder (Gmelina arborea Roxb.) For 12 days at $\mathrm{pH} 6.4$ and water content of $79 \%$ by fungi phanerochaete chrysosporium 
were exposed to gamma ray dose of 600 Gy has an efficiency of lignin degradation by $42 \%$, whereas on fungi ganoderma lucidum that are exposed gamma ray dose of 800 Gy has an efficiency of lignin degradation by $21 \%$ with optimal conditions of $\mathrm{pH} 7$. And; water content of $71.3 \%$

Keywords: phanerochaete chrysosporium, ganoderma lucidum, LiP enzyme, gamma rays radiation, lignin degradation.

\section{PENDAHULUAN}

Limbah forestry dalam aktifitas industri perkayuan merupakan limbah padat berupa serpihan kulit kayu, potongan kayu berukuran kecil (chips wood) dan serbuk kayu atau butiran-butiran halus yang terbuang saat kayu dipotong dengan gergaji (1). Limbah ini mengandung bahan lignoselulosa yang sulit didegradasi. Lignoselulosa adalah makro-molekul kompleks yang terdiri dari lignin, selulosa dan hemiselulosa. Proses degradasi lignoselulosa adalah susunan yang heterogen dari polisakarida yang terdapat pada dinding sel. Selulosa merupakan polimer linier dari Dglukosa yang terikat pada ikatan 1,4 glikosidik dan sangat erat berasosiasi dengan hemi-selulosa dan lignin. Lignin adalah polimer yang sangat tidak teratur dan tidak larut, memiliki ikatan kovalen dengan hemiselulosa (2).

Fungi lignoselulotik dari kelompok white rot fungi merupakan mikroorganisme yang paling aktif dalam mendegradasi lignin dengan menghasilkan $\mathrm{CO}_{2}$ dan $\mathrm{H}_{2} \mathrm{O}$ (3). Fungi Phanerochaete chrysosporium dan ganoderma lucidum dianggap baik karena memiliki kemampuan lignolitik, yakni mampu menghasilkan enzim lignin peroksidase (LiP) dan mangan peroksidase $(\mathrm{MnP})$ yang dapat mendegradasi lignin. Karena lignin merupakan senyawa yang heterogen dengan berbagai tipe ikatan sehingga tidak dapat diuraikan oleh enzim hidrolisis. Fungi ini telah dipertimbangkan dalam produksi enzim pendegradasi lignin dalam penerapan biokonversi lignoselulosa.

LiP adalah enzim peroksidase ekstraseluler yang aktivitasnya bergantung pada $\mathrm{H}_{2} \mathrm{O}_{2}$. veratryl alkohol merupakan produk metabolit sekunder. Veratryl alkohol merupakan substrat untuk menstimulasi kinerja LiP bukan sebagai mediator elektron tetapi dengan mendonasikan elektron ke LiP, sehingga melengkapi siklus katalitiknya (4).

Penggunaan fungi phanerochaete chrysosporium dan ganoderma lucidum yang dikombinasikan dengan proses Solid State Fermentation (SSF) mampu menghasilkan produk yang lebih baik. Hal ini dikarenakan selama proses fermentasi akan membawa fungi atau mikroba yang telah dikultivasi berinteraksi dengan kuat pada substrat yang tidak larut air serta mendapatkan konsentrasi nutrisi tertinggi dari substrat (5). (Bhargav et al., 2008). Fermentasi substrat padat atau Solid State Fermentation (SSF) didefinisikan sebagai proses fermentasi oleh mikroorganisme yang tumbuh dalam material padat tanpa adanya air bebas.

Iradiasi gamma dosis rendah berpengaruh terhadap percepatan aktivitas enzim oleh mikroba (6,7). Trichoderma 
Pengaruh Radiasi Sinar Gamma Terhadap Kemampuan

Degradasi Lignin Phanerochaete Chrysosporium dan

Ganoderma Lucidum

ISSN $1411-3481$

(Tri Retno D.L.)

harzinum, trichoderma viridie dan trichoderma knongii yang diiradiasi gamma pada dosis 500 Gray dapat memproduksi exo-enzim yang sangat aktif sehingga mampu menurunkan pertumbuhan fungi patogen dengan prosentase tertinggi (8).

Penelitian ini bertujuan untuk mengetahui pengaruh iradiasi sinar gamma dosis rendah (0, 200 Gy, 400 Gy, 600 Gy, 800 Gy dan 1000 Gy) terhadap kinerja aktivitas enzim LiP yang dihasilkan oleh fungi P.chrysosporium dan G.lucidum. pada substrat serbuk kayu jati putih (Gmelina arborea Roxb.) dengan menggunakan metode SSF pada kondisi optimal

\section{BAHAN DAN METODE}

\subsection{Bahan dan Alat.}

Bahan utama yang digunakan adalah kultur Phanerochaete chrysosprorium, dan Ganoderma sp. hasil biakan Laboratorium Biologi Universitas Nusa Bangsa (UNB) Bogor, LA (Lignin-Alkali), serbuk kayu jati putih (Gmelina arborea Roxb.) Potato Dextrose Agar (PDA), $\mathrm{KH}_{2} \mathrm{PO}_{4}$, $\mathrm{MgSO}_{4} .7 \mathrm{H}_{2} \mathrm{O}, \quad \mathrm{CaCl}_{2} .2 \mathrm{H}_{2} \mathrm{O}, \quad \mathrm{FeSO}_{4} .7 \mathrm{H}_{2} \mathrm{O}$, Yeast ekstrak, alkohol $70 \%, \mathrm{MnSO}_{4}, \mathrm{H}_{2} \mathrm{O}_{2}$, veratryl alcohol, aquades, aluminium foil, kapas dan kertas label.

Alat yang digunakan antara lain: autoclave, oven, laminar air flow, timbangan digital, inkubator, rotary shaker, kertas saring Whatmann no.1, spektrofotometer tipe $20 \mathrm{D}$, magnetic stirrer, ose, hand sprayer, Bunsen, petri disk, sumber isotop Cobalt-60 dalam gamma chamber 4000A dengan laju dosis 2,1 kGy/jam, dan peralatan gelas lainnya.

\subsection{Tata Kerja}

\subsubsection{Preparasi Kultur Fungi.}

Medium Dasar yang digunakan terdiri dari larutan garam mineral. Komposisi medium dasar dalam 1 liter aquades terdiri dari $1 \mathrm{~g} \quad \mathrm{MgSO}_{4} 7 \mathrm{H}_{2} \mathrm{O} ; 1,5 \mathrm{~g} \quad \mathrm{KH}_{2} \mathrm{PO}_{4} ; 0,2 \mathrm{~g}$ $\mathrm{CaCl}_{2} \cdot 2 \mathrm{H}_{2} \mathrm{O} ; \quad 0,2 \mathrm{~g} \quad \mathrm{FeSO}_{4} . \quad 7 \mathrm{H}_{2} \mathrm{O} ; \quad 0,2 \mathrm{~g}$ $\mathrm{MnSO}_{4} ; 2 \mathrm{~g}$ yeast ekstrak. Komposisi Media dasar dimodifikasi dari Pointing (1999) (9).

Medium Lignin Agar (LA) adalah medium yang mengandung medium dasar sebanyak 1 liter $16 \mathrm{~g}$ agar, lignin alkali (Sigma) $0,25 \% \quad$ (w/v) dan $100 \quad \mathrm{mg}$ chloramphenicol. Medium dimodifikasi dari Marginingrum (2001) (10).

Isolat fungi $P$. chrysosprorium, dan $G$. lucidum ditumbuhkan pada tabung reaksi yang berisi $25 \mathrm{~mL}$ medium PDA (Slent) miring). Kemudian diinkubasi 3-7 hari pada suhu $28-30{ }^{\circ} \mathrm{C}$. di tempat gelap. Viabilitas dan pertumbuhan fungi diamati.

\subsubsection{Iradiasi Fungi}

Perkembangbiakan Phanerochaete chrysosprorium, dan Ganoderma sp yang berumur 3 - 7 hari tersebut kemudian diiradiasi sinar Gamma isotop Cobalt-60 dalam gamma chamber 4000 A dengan laju dosis 2,1 kGy/jam. Dosis iradiasi yang digunakan adalah 0 Gy (kontrol, tanpa iradiasi); 200 Gy; 400 Gy; 600 Gy; 800 Gy dan $1000 \mathrm{~Gy}$.

\subsubsection{Pertumbuhan dan Aktivitas Lignin Peroksidase Fungi Dalam Lignin Alkali}

Disiapkan botol yang berukuran 250 $\mathrm{mL}$ kemudian ditambahkan $30 \mathrm{ml}$ larutan nutrisi dan garam mineral, ditambahkan 
Lignin Alkali (sigma) 0,1\%. Setiap liter larutan nutrisi dan garam mineral mengandung 24g PDB, $1 \mathrm{~g}\left(\mathrm{NH}_{4}\right)_{2} \mathrm{SO}_{4}, 0,5 \mathrm{~g}$ $\mathrm{KH}_{2} \mathrm{PO}_{4}, \quad 0,5 \mathrm{~g} \quad \mathrm{~K}_{2} \mathrm{HPO}_{4}$ dan $0,2 \mathrm{~g}$ $\mathrm{MgSO}_{4} \cdot 7 \mathrm{H}_{2} \mathrm{O}$. Semua medium SmF disterilkan dengan autoklaf pada $121^{\circ} \mathrm{C}$ selama 2x15 menit kemudian didinginkan. Ke dalam $30 \mathrm{~mL}$ medium SmF steril diinokulasi $1 \mathrm{~mL}$ kultur cair fungi Phanerochaete chrysosporium dan Ganoderma, sp dengan kerapatan masing-masing sekitar $10^{6}$ spora/mL, kemudian diinkubasi dalam shaker mekanis pada $75 \mathrm{rpm}$ dan suhu ruang $28-32{ }^{\circ} \mathrm{C}$ selama 4 hari

\subsubsection{Uji Aktivitas Enzim Lignin Peroksidase}

Sebanyak 0,2 $\mathrm{mL}$ filtrat enzim, 0,05 $\mathrm{mL} \mathrm{H}_{2} \mathrm{O}_{2} 5 \mathrm{mM} ; 0,1 \mathrm{~mL}$ veratril alcohol 8 $\mathrm{mM} ; 0,2 \mathrm{~mL}$ buffer asetat $0,05 \mathrm{M} \mathrm{pH} 3$ dan 0,45 $\mathrm{mL}$ akuades dimasukkan ke dalam tabung reaksi kemudian dikocok (11). Larutan tersebut dibaca absorbansinya pada panjang gelombang $310 \mathrm{~nm}$ pada interval waktu 0 dan 10 menit. Satu unit aktivitas enzim LiP didefinisikan sebagai jumlah enzim yang menyebabkan pengubahan 1 mikromol $\left(1 \mu \mathrm{mol}=10^{-6}\right) \mathrm{mol}$ veratril alkohol per menit.

\subsubsection{Fermentasi Substrat Padat Serbuk Kayu jati putih}

Sebanyak $5 \mathrm{~g}$ (berat kering) substrat serbuk kayu jati putih dimasukkan ke dalam plastik ditambahkan $10 \mathrm{~mL}$ larutan nutrisi dan garam mineral. Setiap liter larutan nutrisi dan garam mineral mengandung $1 \mathrm{~g}$ $\left(\mathrm{NH}_{4}\right)_{2} \mathrm{SO}_{4}, 0,5 \mathrm{~g} \mathrm{KH}_{2} \mathrm{PO}_{4}, 0,5 \mathrm{~g} \mathrm{~K}_{2} \mathrm{HPO}_{4}$ dan
$0,2 \mathrm{~g} \mathrm{MgSO}_{4} \cdot 7 \mathrm{H}_{2} \mathrm{O}$. Akuades di-tambahkan ke dalam substrat sehingga diperoleh perbandingan substrat dan cairan sekitar 1 : 2,5 atau kadar kelembaban sekitar 89,5\% (12). Ke dalam substrat steril diinokulasi kultur cair fungi Phanerochaete chrysosporium dan Ganoderma, sp sesuai dengan perlakuan pada rancangan penelitian. Inokulasi kultur cair fungi dengan kerapatan masing - masing sekitar $10^{6}$ spora/mL dilakukan secara aseptik di dalam laminar air flow. Substrat yang tidak diinokulasi kultur cair fungi digunakan sebagai kontrol. Semua substrat dalam plastic ditutup rapat dan diinkubasi di ruang gelap (tanpa pencahayaan) pada $28-32^{\circ} \mathrm{C}$ selama 12 hari.

Pengukuran parameter $\mathrm{pH}$, bobot biomassa mikroba dan aktivitas enzim LiP dilakukan pada hari ke-4 masa pertumbuhan kedua fungi tersebut. Sedangkan pengukuran parameter $\mathrm{pH}$, kadar air dan kadar bahan organik dilakukan pada hari ke-0, 4, 8 dan 12 selama proses SSF berlangsung. Evaluasi kadar lignin, selulosa, hemiselulosa, zat ekstratif, kadar abu dan efisiensi degradasi lignin dilakukan pada awal dan akhir proses SSF (hari ke-12).

\section{HASIL DAN PEMBAHASAN}

\subsection{Pertumbuhan Fungi.}

\subsubsection{Nilai $\mathrm{pH}$}

Laju pertumbuhan mikroba selama proses kultivasi maupun pada proses SSF dipengaruhi nilai $\mathrm{pH}$ substrat. Nilai $\mathrm{pH}$ bergantung pada jenis substrat dan mikroorganisme yang digunakan. Pertumbuhan fungi P.chrysosporium berada pada kisaran 
pH 3.8 - 5.7 pada waktu optimal 4 hari. Nilai $\mathrm{pH}$ tersebut masih dalam rentang $\mathrm{pH}$ pertumbuhan bagi $P$. chrysosporium yaitu pada pH 4 - 7. Sedangkan, G.lucidium tumbuh pada $\mathrm{pH}$ kisaran 4.5-5.3. Rentang $\mathrm{pH}$ untuk pertumbuhan fungi pada umumnya akan tumbuh pada kisaran $\mathrm{pH}$ yang cukup luas yaitu antara 4,5 - 8,0 (13). Nilai pH juga merupakan faktor yang mempengaruhi kerja enzim. Kondisi $\mathrm{pH}$ yang optimum akan membantu enzim untuk mengkatalis suatu reaksi dengan baik. Enzim tidak dapat bekerja pada $\mathrm{pH}$ yang terlalu rendah atau $\mathrm{pH}$ yang terlalu tinggi karena akan mengakibatkan enzim terdenaturasi sehingga sisi aktif enzim terganggu (14).

Perubahan nilai $\mathrm{pH}$ disebabkan oleh adanya perubahan dalam kesetimbangan ion hidrogen karena pengaruh pembentukan produk, pengambilan nutrien, reaksi oksidasi reduksi serta perubahan kapasitas buffer. Penurunan $\mathrm{pH}$ disebabkan adanya pembentukan asam - asam organik seperti asam piruvat dan asam laktat. Kenaikan $\mathrm{pH}$ disebabkan oleh dilepaskan-nya amonia sebagai hasil metabolisme ammonium sulfat dan adanya proses deaminasi substrat protein dalam medium (15).

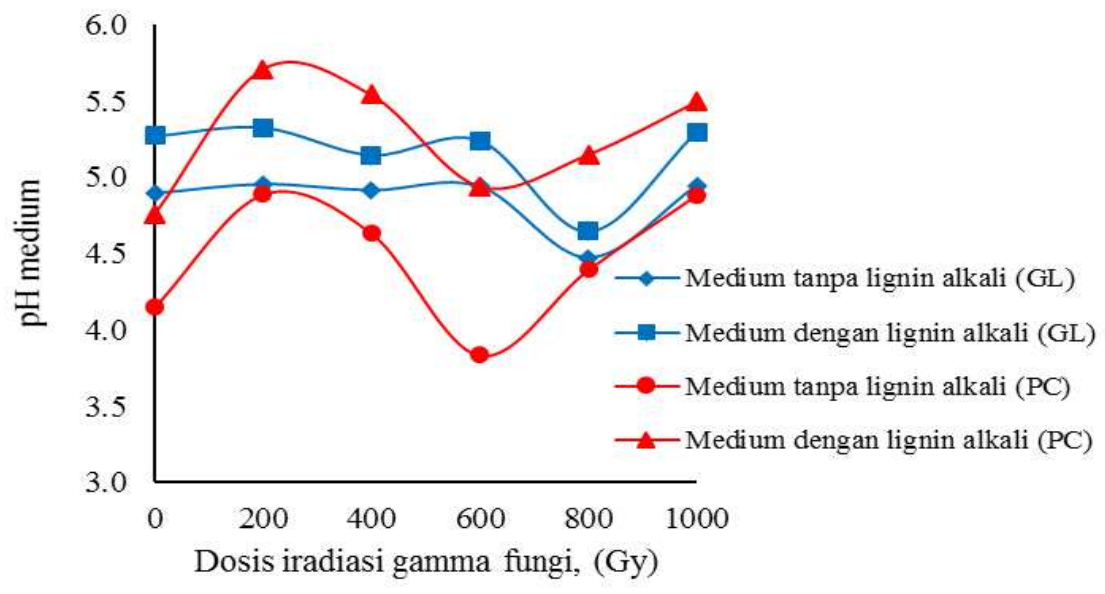

Gambar 1. Pengaruh radiasi gamma terhadap nilai $\mathrm{pH}$ selama pertumbuhan fungi.

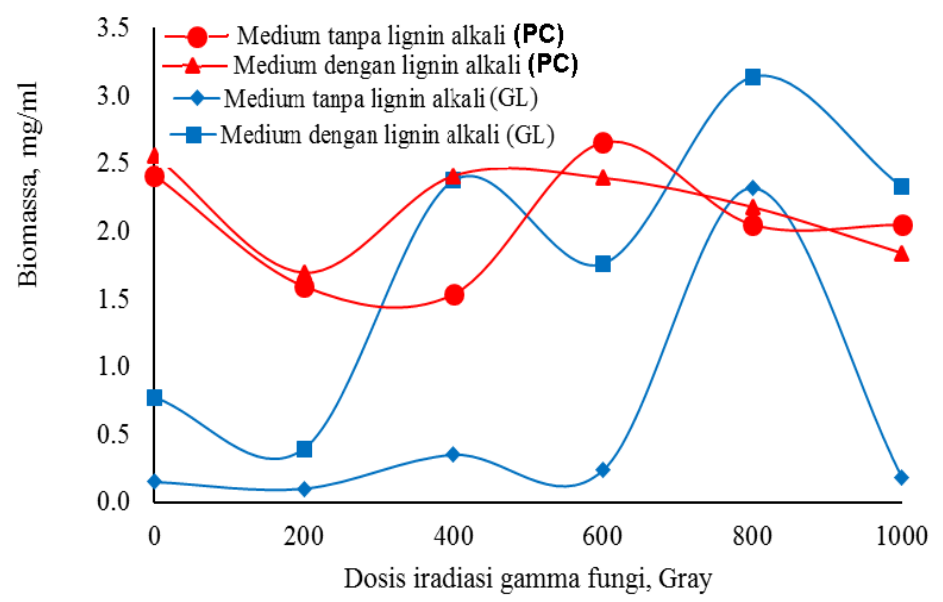

Gambar 2. Pengaruh radiasi gamma terhadap bobot biomassa fungi. 


\subsubsection{Bobot Biomassa Mikroba}

Bobot biomassa fungi ditentukan me-lalui proses pemisahan antara fungi dengan substratnya. Pertumbuhan fungi dapat ditandai dengan peningkatan jumlah dan massa sel sedangkan kecepatan pertumbuhan tergantung pada lingkungan fisik dan kimianya.

Gambar 2. menunjukkan pe-ngaruh radiasi sinar gamma terhadap bio-massa pertumbuhan fungi $P$. chrysosporium dan $G$. lucidum dengan maupun tanpa substrat lignin alkali pada hari ke-4. Peningkatan dosis radiasi sinar gamma dapat menurunkan jumlah mikroorganisme.

Pertumbuhan fungi berlangsung dengan memanfaatkan nutrien yang terdapat dalam medium fermentasi sekaligus mengeluarkan produk-produk metabolisme. Gambar 2 menunjukkan bahwa bobot biomassa pada masing - masing dosis berbeda, pada dosis $0 \mathrm{~Gy}$ atau tanpa iradiasi biomassa yang dihasilkan kecil tetapi pada fungi yang telah di iradiasi biomassa mengalami peningkatan tetapi ada juga yang menurun Perlakuan dengan Lignin Alkali (Sigma) pada G. lucidum menghasilkan biomassa sebesar $3,1 \mathrm{mg} / \mathrm{ml}$ lebih tinggi dibandingkan tanpa menggunakan Lignin Alkali (Sigma) sebesar 2,3 $\mathrm{mg} / \mathrm{ml}$. Hal ini disebabkan nutrisi yang terkandung pada lignin alkali lebih optimal sebagai medium pertumbuhan fungi G. lucidum. Sedangkan perlakuan dengan lignin alkali pada fungi P.chrysosporium tidak memberikan pengaruh yang signifikan karena nutrisi yang ada pada substrat dapat bersaing dengan nutrisi dalam lignin alkali, sehingga fungi dapat berkembang dengan cepat tanpa lignin. Pertumbuhan biomassa fungi akan mengalami penurunan jika banyak fungi yang mati. Hal ini disebabkan karena habisnya nutrisi yang terkandung dalam medium sehingga menyebabkan beberapa sel fungi mati (16). Hasil penelitian sebelumnya menunjukan bahwa pengaruh iradiasi gamma terhadap pertumbuhan P.sajor-caju terjadi penurunan bertahap pada pertumbuhan diameter cakram miselium karena dosis radiasi gamma meningkat (17).

Hal ini mungkin dasar penjelasan bahwa variasi dosis radiasi gamma dapat merusak sel DNA, sehingga secara bersamaan dibutuhkan perbaikan DNA dari sejumlah enzim untuk mengembalikan integritas genomik. Pertumbuhan $P$. chrysosporium dan G. lucidum pada dosis iradiasi yang diberikan tumbuh dengan baik pada dosis rendah. Pertumbuh-an $P$. chrysosporium optimal pada dosis 600 Gy sedangkan pertumbuhan $G$. lucidum optimal pada dosis 800 Gy. Iradiasi Gamma dosis rendah dapat digunakan untuk meningkatkan kinerja pertumbuhan mikroorganisme dengan baik yang penting untuk melakukan biodegradasi(18).

\subsubsection{Aktivitas enzim LiP}

Dosis optimum radiasi sinar gamma ditentukan melalui pengujian aktivitas enzim LiP. Aktivitas enzim LiP pada Phanerochaete chrysosporium dan Ganoderma lucidum dengan dosis iradiasi 0 , $200,400,600,800$ dan 1000 Gy dapat dilihat pada Gambar 3. 


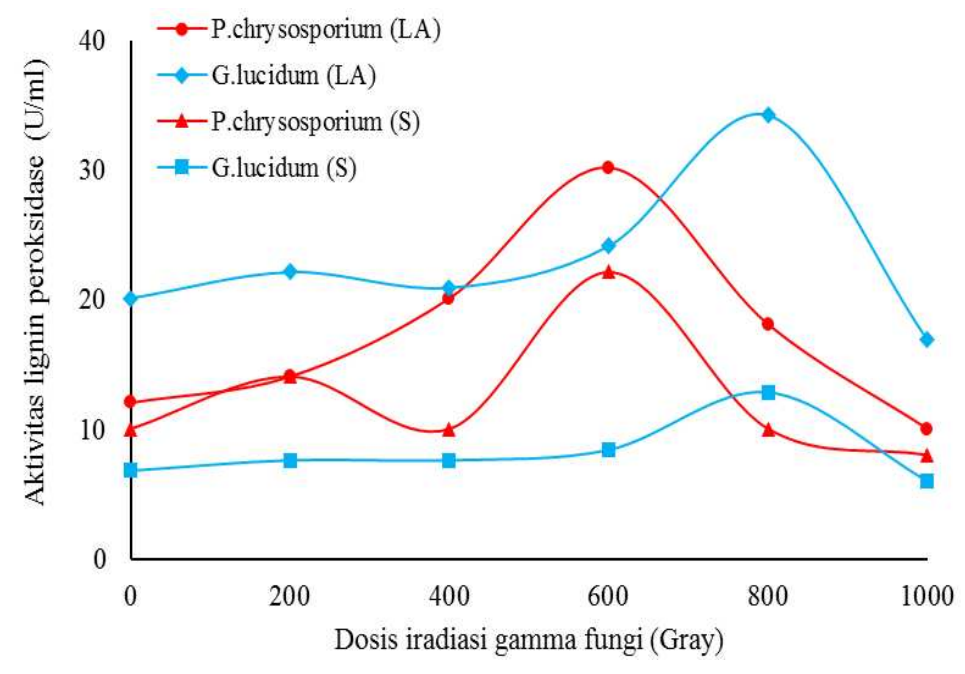

Gambar 3. Pengaruh radiasi gamma terhadap aktivitas LiP fungi.

Grafik kelangsungan hidup spora Phanerochaete chrysosporium menunjukkan kenaikan viabilitas karena radiasi yang menstimulasi germinasi (19). Hasil penelitian sebelumnya menunjukkan bahwa radiasi gamma dapat mengubah struktur genom. Kerusakan untaian ganda genom lebih efektif menggunakan perpindahan energi cahaya tinggi dari pada perpindahan energi rendah (20).

Dalam kemampuannya mendegradasi lignin, enzim peroksidase terlebih dahulu dioksidasi oleh $\mathrm{H}_{2} \mathrm{O}_{2}$, yang juga dihasilkan oleh fungi, untuk membentuk zat antara. Zat ini selanjutnya direduksi oleh sebuah elektron dan membentuk zat kedua yang bersifat radikal. Selanjutnya zat kedua mengoksidasi substrat berikutnya dengan satu elektron sehingga siklus katalitis tersebut lengkap. Senyawa veratril alkohol merupakan metabolit sekunder yang juga dihasilkan oleh jamur. Ditemukan bahwa beberapa substrat tertentu yang tidak dapat dioksidasi oleh lignin peroksidase akan teroksidasi jika di dalam campuran inkubasi terdapat veratril alkohol (21). $\mathrm{H}_{2} \mathrm{O}_{2}$ dan veratril alkohol merupakan mediator dalam proses biodelignifikasi (22).

Interaksi sinar gamma dengan suatu sel akan menghasilkan radikal bebas atau spesi oksigen reaktif di antaranya adalah radikal superoksida $\left(\mathrm{O}^{-2}\right)$, radikal hidroksil $\left(\mathrm{OH}^{\cdot}\right)$, dan hidrogen peroksida $\left(\mathrm{H}_{2} \mathrm{O}_{2}\right)$. Radikal bebas tersebut dapat menggangu struktur dan fungsi dari komponen sel sehingga memicu terjadinya stres oksidatif. Sebagai akibat dari stress yang ditimbulkan, sel tersebut akan mengembangkan mekanisme proteksi untuk melawan efek oksigen reaktif dengan menghasilkan enzim yang lebih banyak (23). Lydia et al., 1994, juga menyatakan bahwa mutasi akibat radiasi menyebabkan fungi terstimulasi kemudian memperbaiki bagian terinduksi untuk menghasilkan enzim yang lebih banyak daripada sebelum diradiasi (24).

Analisa aktivitas enzim Lignin Peroksida (LiP) dilakukan dengan cara metode 
Sub-merged Fermentation dengan beda perlakuan dalam waktu 4 hari. LiP adalah enzim peroksidase ekstraseluler yang aktivitasnya bergantung pada $\mathrm{H}_{2} \mathrm{O}_{2}$ (25). Dalam metabolismenya, fungi pelapuk putih ini memproduksi suatu zat dengan berat molekul rendah yang merupakan kofaktor atau mediator bagi kerja enzim. Mediator ini bersama sama dengan enzim lignin peroksidase akan berfungsi aktif dalam pendegradasian lignin. Mediator yang dibutuhkan oleh enzim lignin peroksidase adalah veratryl alkohol dan hidrogen peroksida $\left(\mathrm{H}_{2} \mathrm{O}_{2}\right)$. Penambahan $\mathrm{H}_{2} \mathrm{O}_{2}$ berfungsi sebagai reduktor yang akan mengoksidasi enzim pada keadaan awal (restyng enzyme) dengan dua elektron membentuk senyawa intermediet I. Sedangkan penambahan veratril alcohol berfungsi sebagai mediator dalam reaksi redoks untuk menstimulasi oksidasi LiP pada substrat limbah organik lignoselulosa (26). Dengan penambahan veratril alcohol sebagai kosubstrat, maka kosubstrat ini akan dioksidasi oleh peroksida menjadi suatu kation radikal yang kemudian mendegradasi lignin. Pada penambahan buffer asetat ber-fungsi sebagai larutan penyangga untuk mempertahankan $\mathrm{pH}$ pada saat terjadinya reaksi enzimatis, pada $\mathrm{pH} 3$ yang me-rupakan $\mathrm{pH}$ optimum untuk menghasilkan aktifitas LiP yang maksimum. Pengukuran dilakukan dengan spektrofotometer pada panjang gelombang $310 \mathrm{~nm}$ karena jumlah veratryl aldehid yang terbentuk dapat dibaca pada panjang gelombang tersebut. Pada Gambar 3 menunjukkan bahwa aktivitas enzim LiP menggunakan substrat lignin alkali lebih tinggi dibandingkan dengan yang menggunakan substrat serbuk kayu. Aktivitas enzim LiP pada G.lucidum lebih tinggi dengan menggunakan lignin alkali (Sigma) dibandingkan dengan menggunakan substrat serbuk kayu dengan nilai 34 $\mathrm{U} / \mathrm{ml}$ pada dosis $800 \mathrm{~Gy}$. Aktivitas enzim LiP pada $P$. chrysosporium menggunakan lignin alkali (Sigma) mencapai $30 \mathrm{U} / \mathrm{ml}$ pada dosis 600 Gy. Pada P. chrysosporium kenaikannya terlihat tidak signifikan tetapi pada dosis yang optimal $P$. chrysosporium lebih tinggi aktivitas LiP dibandingkan dengan $G$. lucidum. Hasil yang diperoleh menunjukkan bahwa aktivitas LiP mengguna-kan lignin alkali (sigma) lebih tinggi dari pada substrat serbuk kayu, karena lignin alkali (sigma) mengandung banyak sumber karbon. Aktivitas enzim LiP tertinggi di-tunjukan oleh G.lucidum, aktivitas enzim ini memang lebih tinggi daripada aktivitas enzim $P$. chrysosporium (27).

\subsection{Proses SSF(Solid State Fermentation)}

\subsubsection{Nilai $\mathrm{pH}$}

Nilai $\mathrm{pH}$ merupakan salah satu parameter yang mempengaruhi pertumbuhan fungi dan proses fermentasi. Perubahan $\mathrm{pH}$ selama proses fermentasi pada $P$. chrysosporium ditunjukkan pada Gambar 4. Hasil yang diperoleh menunjukkan bahwa $\mathrm{pH}$ P. chrysosporium selama proses fermentasi memiliki nilai yang fluktuatif. Nilai $\mathrm{pH}$ yang dihasilkan berada pada kisaran 5,9 sampai 7,8 .

Rentang nilai $\mathrm{pH}$ tersebut masih dalam rentang $\mathrm{pH}$ pertumbuhan yang optimum bagi $P$. chrysosporium yaitu pada pH 4 - 7 (13).

Perubahan nilai $\mathrm{pH}$ pada $\mathrm{G}$. lucidum 
selama proses fermentasi dapat dilihat juga pada Gambar 5. Nilai $\mathrm{pH}$ pada G. Iucidum selama proses fermentasi memiliki perubahan nilai yang cukup signifikan.

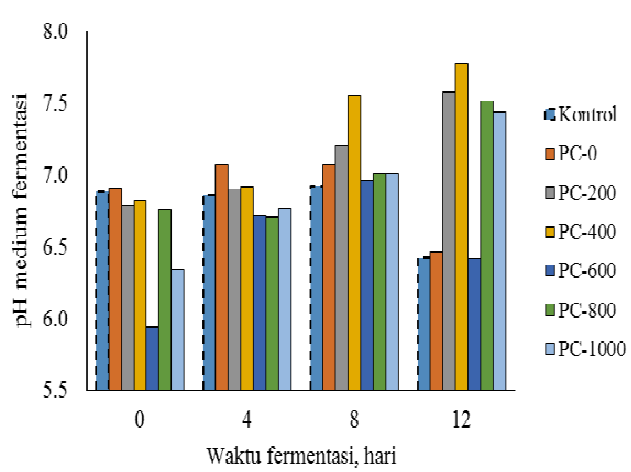

Gambar 4. Nilai pH pada P. Chrysosporium fermentasi 12 hari.

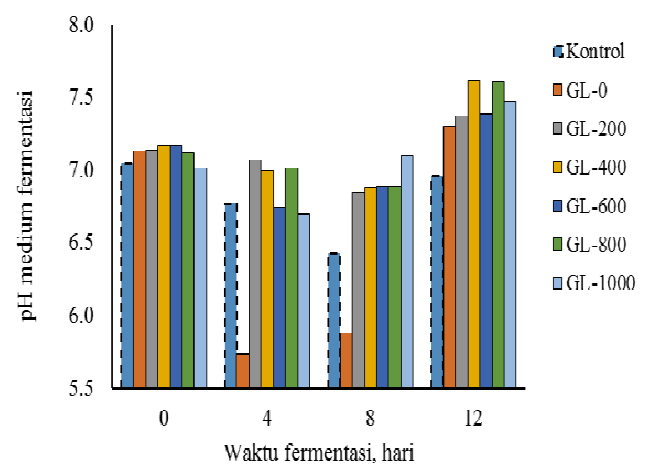

Gambar 5. Nilai pH pada G.lucidum selama fermentasi 12 hari.

Nilai pH G. lucidum selama proses fermentasi berada pada kisaran 5,7 sampai 7,6. Pada Gambar 4 dan Gambar 5 perubahan nilai $\mathrm{pH}$ yang baik antara kedua fungi terlihat di hari ke 4 karena pada hari ke 5 nilai $\mathrm{pH}$ kedua fungi sudah sebagian meningkat.

Perubahan nilai pH disebabkan oleh adanya perubahan dalam kesetimbangan ion hidrogen yang mungkin terjadi karena pengaruh pembentukan produk, peng- ambilan nutrien, reaksi oksidasi reduksi serta perubahan dalam kapasitas buffer. Penurunan $\mathrm{pH}$ disebabkan karena adanya pembentukan asam-asam organik seperti asam piruvat dan asam laktat.

\subsubsection{Kadar air}

Berdasarkan hasil penelitian, kadar air substrat serbuk kayu pada P.chrysosporium selama fermentasi mengalami peningkatan pada hari ke-4. Hasilnya dapat dilihat pada Gambar 6. Pada hari ke-4 semua perlakuan mengalami kenaikan dan mempunyai kadar air yang tinggi hingga mendekati $100 \%$ untuk $P$. chrysosporium yang tidak diiradiasi, diiradiasi dengan dosis $600 \mathrm{~Gy}$, dan $800 \mathrm{~Gy}$. Pada hari ke-8 dan ke-12 juga tidak ada perbedaan pada masing-masing dosis.

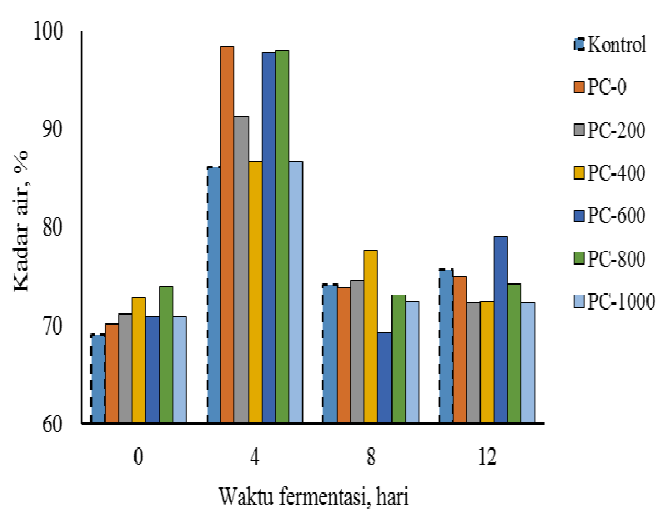

Gambar 6. Kadar air pada P.chrysosporium.

Kadar air pada G. Iucidum juga mengalami peningkatan pada hari ke-4 tampak pada Gambar 7. Kadar air G. Iucidum pada hari ke-4 semua dosis mengalami peningkatan, tetapi pada hari ke-8 beberapa dosis mengalami kenaikan juga, yaitu pada G .lucidum tanpa iradiasi, 200 Gy, 400 Gy, dan 1000 Gy. Pada hari ke-12 semua dosis 
mengalami penurunan yang cukup signifikan. Pada hari ke-4 ada perbedaan dari masing masing dosis yang cukup signifikan dan pada hari ke-8 perbedaan yang didapatkan tidak terlalu signifikan dan pada hari ke-12 juga ada perbedaan pada masing-masing dosis yang cukup signifikan.

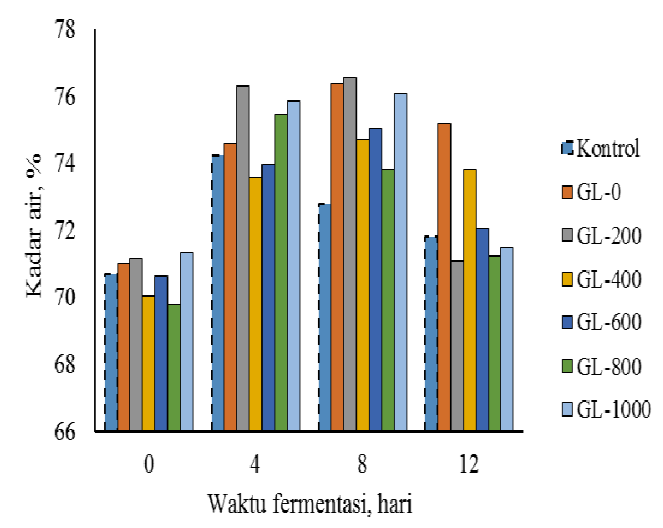

Gambar 7. Kadar air pada G.lucidum.

Pada proses fermentasi, kadar air berfungsi untuk proses transport nutrien dan produk-produk metabolit melalui membran sel (28). Peningkatan kadar air yang terjadi di-sebabkan karena semakin lama waktu fermentasi, aktivitas $P$. chrysosporium dan G. lucidum juga semakin meningkat.

Hal ini terjadi karena pada proses fermentasi terjadi perombakan karbohidrat menjadi gula-gula sederhana yang kemudian diubah menjadi energi dengan hasil sampingan berupa metabolit, alkohol, asam, karbondioksida $\left(\mathrm{CO}_{2}\right)$ dan air $\left(\mathrm{H}_{2} \mathrm{O}\right)$ sehingga akan meningkatkan kadar air pada bahan kering (29).

Hal tersebut menunjukkan bahwa kadar air yang tinggi disebabkan karena semakin lama proses fermentasi maka perubahan glukosa menjadi $\mathrm{CO}_{2}$ dan $\mathrm{H}_{2} \mathrm{O}$ semakin tinggi.
Kadar air yang berada di bawah level kritis, aktivitas mikroba akan turun, sementara kadar air yang terlalu tinggi akan menghambat pergerakan udara dalam substrat. Kadar air substrat yang terlalu tinggi pada fermentasi media padat menyebabkan udara yang terdapat pada pori-pori subtrat digantikan oleh air, tercipta kondisi anaerob, mengurangi difusi oksigen dan penurunan dekomposisi substrat (30).

\subsubsection{Kadar Lignoselulosa}

Kandungan lignoselulosa pada kayu terdiri dari selulosa, hemiselulosa, lignin dan zat ekstratif. Perubahan kandungan lignin pada substrat terjadi karena perombakan struktur lignin menjadi komponen yang lebih sederhana. Penurunan kadar lignin diikuti dengan meningkatnya kadar selulosa pada substrat. Tabel 1 menunjukkan kadar lignoselulosa dari substrat kayu dalam proses SSF selama 12 hari menggunakan fungi $P$. chrysosporium.

Tabel 1. Kadar lignoselulosa proses SSF selama 12hari pada P.chrysosporium

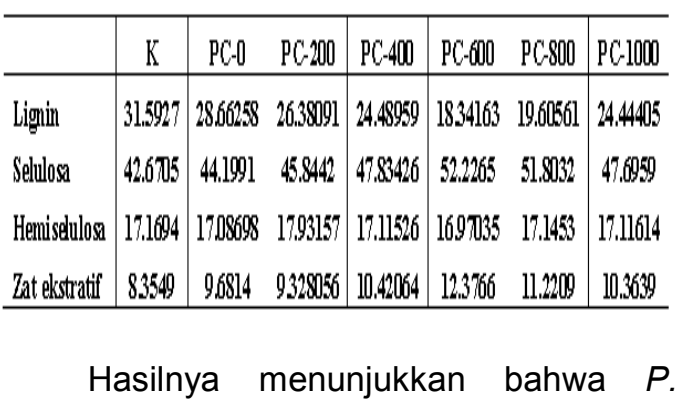
chrysosporium yang distimulasi radiasi sinar gamma dengan dosis 600 Gy memberikan penurunan lignin optimal se-besar $18,3 \%$ dan peningkatan selulosa mencapai $52,2 \%$., kadar hemiselulosa sebesar $17 \%$ dan zat ekstratif sebesar $12,4 \%$. 
Tabel. 2 menunjukkan kadar lignoselulosa dari substrat kayu dalam proses SSF selama 12 hari menggunakan fungi $G$. lucidum. Hasilnya menunjukkan bahwa $G$. lucidum yang distimulasi radiasi sinar gamma dengan dosis 800 Gy memberikan penurunan lignin optimal sebesar $24,9 \%$ dan peningkatan selulosa mencapai $52,3 \%$, kadar hemi-selulosa sebesar $14,5 \%$ dan zat ekstratif sebesar $8,1 \%$.

Tabel 2. Kadar lignoselulosa proses SSF selama 12 hari pada G.Iucidum

\begin{tabular}{|c|c|c|c|c|c|c|c|}
\hline & $\mathrm{K}$ & $\mathrm{GL}-\mathrm{D}$ & CLL-200 & CL-400 & GL-60] & GL-SDO & GL-1000 \\
\hline Liginin & 31.5919 & 26,671 & 26,638 & 26,1317 & 26,4777 & 24.913 & 26.4 \\
\hline Selulos & 42.6705 & 49,04464 & 51,0149 & 50,838 & $50,8085]$ & 5230245 & 50,84782 \\
\hline Heniseluloog & 17.1694 & 16,0044 & 14,047 & 14,693 & 14,4138 & 14.4845 & 14,4121 \\
\hline Zat ekstratif & 83540 & 8.11 & 781 & 8,07 & 8.16 & 80901 & $7960]$ \\
\hline
\end{tabular}

Perombakan komponen lignoselulosa oleh fungi $P$. chrysosporium dan $G$. lucidum menghasilkan enzim lignolitik yang digunakan untuk mendegradasi lignin.

Hasil perombakan komponen lignoselulosa ini akan dimanfaatkan oleh fungi untuk per-tumbuhan yang berarti akan menekan proses degradasi lignin dan aktivitas degradasi akan terjadi kembali jika ke-tersediaan nutrien dalam media berkurang.

Degradasi lignin akan membuka akses untuk perombakan selulosa dan hemi-selulosa (31). Depolimerisasi dan demineral-isasi lignin oleh fungi menjadi $\mathrm{CO}_{2}$ dan air menyebabkan penurunan kandungan lignin substrat. $P$. chrysosporium dan G. lucidum mempunyai kemampuan untuk men-degradasi lignoselulosa secara selektif dengan mendegradasi lignin lebih dahulu diikuti dengan perombakan hemiselulosa dan selulosa (32).

Zat ekstratif terbentuk dari senyawasenyawa ekstraseluler dan berat molekul rendah, dan kandungan ekstratif dalam kayu umumnya kurang dari $10 \%$. Perubahan kadar zat ekstraktif pada susbtrat kayu diduga karena adanya penguapan za-zat ekstraktif yang bersifat volatil pada suhu fermentasi. Selain itu juga karena jenis ekstraktif pada kayu jati yang bersifat racun terhadap mikroorganisme, menyebabkan fungi Phanerochaete chrysosporium tidak tumbuh dengan baik di media serbuk kayu jati (33).

\subsubsection{Degradasi Lignin}

Proses degradasi lignin dipengaruhi oleh pertumbuhan fungi $P$. chrysosporium dan G. lucidum dalam memproduksi enzim LiP yang dapat mendegradasi lignin. Degradasi lignin merupakan reaksi spontan upaya memenuhi kebutuhan nutrien untuk pertumbuhan. Hasil perombakan komponen lignoselulosa ini akan dimanfaatkan oleh fungi untuk pertumbuhan yang berarti akan menekan proses degradasi lignin dan aktivitas degradasi akan terjadi kembali jika ketersediaan nutrien dalam media berkurang.

Perombakan kandungan lignin oleh fungi pelapuk putih akan melibatkan kerja enzim ligninolitik yang akan menguraikan lignin menjadi karbondioksida $\left(\mathrm{CO}_{2}\right)$, enzim tersebut adalah lignin peroksidase dan mangan peroksidase (34). Enzim ligninolitik ini bekerja aktif dengan adanya oksigen, kunci reaksi degradasi lignin oleh fungi 
pelapuk putih adalah biokatalis enzim ligninase yang mengkatalis oksidasi cincin aromatik lignin untuk melepas ikatan-ikatan pada cincin aromatiknya dan membentuk radikal-radikal kation. Kemudian radikalradikal tersebut menjalani reaksi spontan membawa kearah degradasi lignin, sebagian radikal memecah ikatan intramolekul lignin dan sebagian lagi memecah cincin aromatik (35).

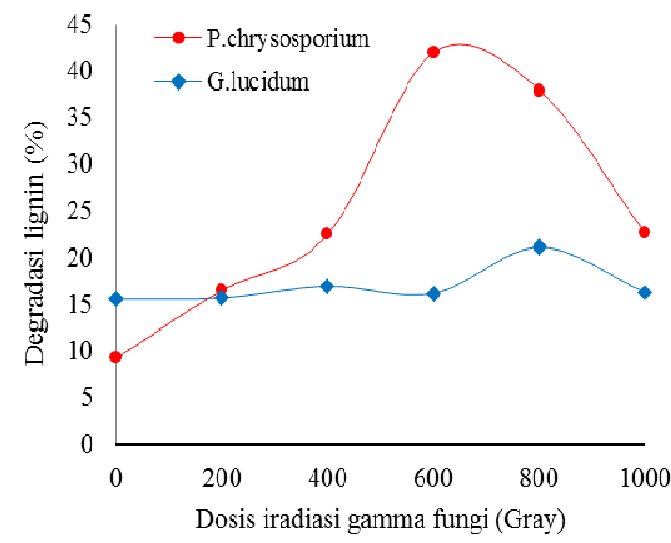

Gambar 8. Dosis radiasi vs degradasi lignin.

Gambar 8 menunjukkan pengaruh radiasi sinar gamma terhadap efisiensi degradasi lignin dari fungi $P$. chrysosporium dan G. Iucidum pada proses SSF selama 12 hari menggunakan substrat serbuk kayu jati putih. Aktivitas fungi P.chrysosporium pada dosis 600 Gy menghasilkan kemampuan degradasi lignin optimal sebesar $42 \%$. Pada penelitian yang sebelumnya menyatakan bahwa degradasi lignin tongkol kapas yang difermentasi dengan P.chrysosporium sebesar $21 \%$ setelah difermentasi selama 4 10 hari. Sedangkan, hasil penelitian Fadilah et al., (2008) yang menggunakan fungi pelapuk putih P.chrysosporium mampu mendegradasi lignin mencapai $81,4 \%$ pada inkubasi selama 30 hari dengan substrat batang jagung (21). Waktu fermentasi berpengaruh terhadap efisiensi degradasi lignin. Dosis yang paling optimal dalam mendegradasi lignin pada G.lucidum berada pada rentang dosis $400 \mathrm{~Gy}-800 \mathrm{~Gy}$. Pada rentang dosis optimal tersebut G. Iucidum mampu mendegradasi lignin hingga $21 \%$ pada dosis 800 Gy lebih rendah jika dibandingkan dengan kemampuan degradasi lignin $P$. chrysosporium.

Dilihat dari kemampuan mendegradasi lignin terhadap kedua fungi pelapuk putih tersebut $P$. chrysosporium lebih baik dalam men-degradasi lignin dibandingkan dengan $G$. lucidum yang menpunyai kemampuan dalam mendegradasi lignin juga tetapi tidak mengalami peningkatan atau kenaikan yang signifikan terhadap setiap dosisnya.

\section{KESIMPULAN}

Perlakuan iradiasi gamma dosis rendah mampu meningkatkan aktivitas enzim LiP dari $P$. chrysosporium dan $G$. lucidum. Fungi $P$. chrysosporium yang diradiasi dengan dosis 600 Gy memberikan aktivitas enzim LiP optimal sebesar $30 \mathrm{U} / \mathrm{ml}$ sedangkan aktivitas enzim LiP yang dihasilkan G. lucidum pada dosis optimal $800 \mathrm{~Gy}$ adalah $34 \mathrm{U} / \mathrm{ml}$. Kemampuan degradasi lignin fungi $P$. chrysosporium sebesar $42 \%$ pada dosis 600 Gy lebih tinggi dibandingkan dengan degradasi lignin dari $G$. lucidum sebesar $21 \%$ pada dosis $800 \mathrm{~Gy}$.

\section{UCAPAN TERIMA KASIH}

Ucapan terima kasih kami sampaikan kepada Srikandi S.Si., M.Si., dari Fakultas 
Pengaruh Radiasi Sinar Gamma Terhadap Kemampuan

Degradasi Lignin Phanerochaete Chrysosporium dan

Ganoderma Lucidum

ISSN $1411-3481$

(Tri Retno D.L.)

MIPA Universitas Nusa Bangsa Bogor serta

Arief Adhari, AMd., dan Marwadi yang telah membantu sehingga penelitian dapat diselesaikan tepat pada waktunya.

\section{DAFTAR PUSTAKA}

1. BPPT Kelompok Teknologi

Pengelolaan Air bersih dan limbah cair.

Petunjuk Teknik Penanganan Limbah

Lingkungan Hidup 2012.

www.kelair.bppt.go.id/ Publikasi/ Buku

PetnisLimbLH/ 06KAYU.pdf. 159-168.

2. Dashtban $H$, Schraft $H$, Syed TA, Qin

W. Fungal biodegradation and enzymatic modification of lignin. Int. Journ. Biochem. Mol. Biol. 2010;1(1):36-50.

3. Sasikumar V, Priya V, C. Shiv Shankar and D. Sathiah Sekar. Isolation and Preliminary screening of lignin degrading microbes (On line), Journal of Academia and Industrial Research 2014; 3: 291-294.

4. Busse N, Wagner D, Kraume M and Czermak P. Reaction Kinetic of Versatile Peroxidase for the degradation of lignin compounds, American Journal of Biochesmistry and Biotechnology, Science Publication 2013;9 (4):365-394.

(http://www.thescipub.com/ajbb.toc)

5. McKinney K, Combs J, Becker P, Humphries A, Filer K and Vriesekoop F. Optimization of phytase production from escherichia coli by altering solid-state fermentation conditions, Fermentation 2015;1: 13-23.

(doi: 10.3390/ fermentation 1010013,
ISSN 2311-5637).

6. Desai AS and Rao S. Effect of gamma radiation on germination and physiological aspects of pigeon pea (cajanus cajan (I.) millsp) seedlings. Intern. Journ. of Research in App.,Natural and Social Sciences 2014; 2(6):47-52.

7. Afify AEMR, Abo-El-Seoud M, Ibrahum GM, Helal IMM and Kassem BW. Exposing of trichodermaspp. to gamma radiation for stimulating its pesticide biodegradation activity, J. Rad. Res. Appl. Sci 2012; 5(2):440454.

8. Ahmed AS, Farag SS, Hassan IA and Botros HW. Production of gluconic acid by using some irradiated microorganisms, Journal of Radiation Research and App. Scien. 2015; 8: 374 -380 .

9. Pointing SB. Qualitative methods for the determination of lignocellulotik enzyme production by tropical fungi. Juornal Fungal Diversity 1999;2: 17-33.

10. Marginingrum D. dan Karningsih N. Studi Degradasi lignin ekstraktif menggunakan bakteri serratia marcescens dengan menggunakan metode reaktor batch. Prosiding Seminar Nasional Kimia Pusat Penelitian Geoteknologi LIPI. Surakarta: 2001:149-157.

11. Bonnen $A$ M, Anton $L H$, \& Orth $A B$. Lignin degrading enzymes of the commercial button mushroom, agaricus bisporus. Appl. Environ. Microbiol 1994; 60:960-965. 
12. Pensupa N, Jin M, Kokolski M dan Archer, DB. A Solid state fungal fermentation based strategy for the hydrolysis of wheat straw.J.Bioresource Technology. 2013;149:261-267.

13. Pal $\mathrm{S}$ and Vimala $\mathrm{Y}$. Bioremediation of chromium from fortified solutions by phanerochaete chrysosporium (MTCC 787). J.Bioremed. and Biodegrad 2011; $2: 5$, http://dx.doi.org/ 10.4172/21556199.1000127.

14. Safaria S, Idiawati N dan Zaharah T A. Efektivitas campuran enzim selulase dari aspergillus niger dan trichoderma reesei dalam menghidrolisis substrat sabut kelapa. Jurnal Kimia dan Kemasan. 2013; 2(1): 46-51.

15. Ali SS and Vidhale NN. Protease production by pusarium oxysporum in solid- state fermentation using rice bran, American Journal of Microbiological Research 20131; 3: 45-47.

16. Sivaramanan, S. Isolation of Cellulolytic Fungi and their degradation on cellulosic agricultural wastes. Journal of Academia and Industrial Research (JAIR) 2014; 2: 458-463.

17. Abo-State MAM, Khatab O, Abo-El Nasar A and Mahmoud B. Factors affecting laccase production by pleurotus ostreatus and pleuratus sajor-caju. World applied Sciences Journal 2011;14 (11) : 1607 - 1619.

18. Afify Abd El-Moneim MR, Mohamed A Abo-El-Seoud, Ghada M Ibrahim and Bassam W Kassem. Stimulating of biodegradation of oxamyl pesticide by low dose gamma irradiated fungi. $J$ Plant Pathol Microb 2013;4 (9):1-5
19. Piri I, Babayan M, Tavassoli A and Javaheri M. The use of gamma irradiation in agriculture, African Journal of Micro. Reserch 2011;5 (32):5806-5811.

20. Rastogi RP, Richa, Kumar A,Tyagi MB, and Sinha RP. Molecular mechanisms of ultraviolet radiation-Induced DNA damage and repair, Journal of Nucleic Acids 2010;10:1-32, Article ID 592980, doi:10.4061/2010/592980.

21. Fadilah, Sperisa D, Enny Kris A, Arif J. Biodelignifikasi batang jagung dengan jamur pelapuk putih phanerochaete crysosporium. Ekuilibrium, 2008; 7 (1): 7-11.

22. Irshad $\mathrm{M}$ and Asgher M. Production and optimization of ligninolytic enzymes by white rot fungus Schizophyllum commune IBL-06 in solid state medium banana stalks, African Journal of Biotechnology , 2011;10(79):1823418242, DOI: 10.5897/AJB11.2242 ISSN 1684-5315.

23. Sreedhar M, chaturvedi A., Aparna M. Kumar PD, Singhai RK. and Babu V. Influence of $y$-radiation stress on scavenging enzymes activity and cell ultra structure in groundnut (Arachis hypogaea L.). Applied Science Resource, 2013; 4 (2):35 - 44.

24. Zia MA, Rasul S and Iftikhar T. Effect of gamma irradiation on aspergillus niger for enhanced production of glucose oxidase, Pakistan Journ. Bot 2012; 44(5): 1575-1580.

25. Ima, Ilmi M dan Nengah, Kuswytasari D. Aktifitas enzim lignin peroksidase oleh gliomastix sp. T3.7 pada Limbah 
bonggol jagung dengan berbagai $\mathrm{pH}$ dan suhu. Institut Teknologi Sepuluh Nopember (ITS). Jurnal Sains dan Seni POMITS 2013; 2(1): 2337-3520.

26. Mehboob N, Asad MJ, Imran M, Gulfraz Watoo FH , Hadri SH and Asghar M. Production of lignin peroxidase by ganoderma leucidum using solid state fermentation, African Journal of Biotechnology 2011; 10(48):9880-9887,(online), http://www. academicjournals.org/AJB.

27. Sasidhara $R$ and Thirunalasundari $T$. Lignolytic and lignocellulosic enzymes of ganoderma lucidum in liquid medium, European Journal of Experimental Biology 2014; 4(2):375-379.

28. Hilakore M. Peningkatan kualitas nutritif putak melalui fermentasi campuran trichoderma reesei dan aspergillus niger rebagai rakan rumanisia. Tesis, Institut Pertanian Bogor, Bogor 2008.

29. Sartori T, Tibolla H, Prigol E, Colla LM, Vieira Costa JA, and Bertolin TE. Enzymatic saccharification of lignocellulosic residues by cellulases obtained from solid state fermentation using trichoderma viride. BioMed Research International 2015;10:1-9, Article ID 342716, http://dx.doi.org/10.1155/2015/342716.

30. Haddadin MSY, Haddadin J, arabiyat II and Hattar B. Biological conversion of olive pomace into compost using trichoderma harzianum and phanerochaete chrysosporium. Biores. Technol 2009; $100: 4773-4782$.
31. Zeng G, Yu M, Chen Y, Huang D, Zhang J, Huang $\mathrm{H}$, Jiang $\mathrm{R}$. and $\mathrm{Yu} Z$. Effects of Inoculation with $P$. chrysosporium at various time points on enzyme activities during agricultural waste composting. Biores. Technol 2010; 101: 222 - 227.

32. Batool S, Asgher M, Sheikh MA and Rahman SU. Optimization of physical and nutritional factors for enhanced production of lignin peroxidase by ganoderma lucidum ibl-05 in solid state culture of wheat straw, The Journal of Animal \& Plant Sciences 2013; 23(4): 1166-1176, ISSN: 1018-7081.

33. Irawati D, Azwar NR, Syafii W, dan Artika IM. Pemanfaatan serbuk kayu untuk produksi etanol dengan perlakuan pendahuluan delignifikasi menggunakan jamur phanerochaete chrysosporium. Jurnal Ilmu Kehutanan 2009; 3 (1): 13-22.

34. Gao H, Wang $\mathrm{Y}$, Zhang $\mathrm{W}$, Wang $\mathrm{W}$ and $\mathrm{Mu} Z$. Isolation, identification and application in lignin degradation of an ascomycete GHJ-4, African Journal of Biotechnology 2011;.10(20): 41664174 , http://www.academicjournals.org/AJB, DOI: 10.5897/AJB10.2250, ISSN 16845315.

35. Tišma $M$, Zelic $B$, Vasic-Racki D. White-rot fungi in phenols, dyes and other xenobiotics treatment - a brief review, Croat. J. Food Sci. Technol 2010; 2 (2): 34-47. 
Jurnal Sains dan Teknologi Nuklir Indonesia

Indonesian Journal of Nuclear Science and Technology

Vol. 17, No 1, Februari 2016; 21-36

ISSN 1411 - 3481 